RESENHA BIBLIOGRÁFICA 


\title{
COLEÇÕES ARQUEOLÓGICAS E ASPECTOS DA ARQUEOLOGIA NO URUGUAI(1)
}

\author{
Arno Alvarez Kern *
}

Uma pergunta é muitas vezes formulada aos arqueólogos: "... e quando vocês năo estâo escavando, o que é que vocês fazem?". Esta questáo acima leva aos pesquisadores, um pouco contrafeitos, a responder que estudam em laboratório o material extraído das escavaçōes, e que esta análise é muito mais demorada do que as atividades de escavaçăo (2). Esta resposta, para o público e para os nossos colegas de universidade, nem sempre chega a convencer plenamente. Ela se antepóe a uma atitude muito difundida que privilegia a escavação arqueológica, principalmente pelo que ela tem de dramático que é a descoberta espetacular. O que atrai sempre a atençăo são as notícias sobre a evidenciação das datas mais antigas relacionadas com as origens do povoamento, ou a descoberta das fundaçóes de um edifício desconhecido, enterrado sob os escombros dos séculos. Para reforçar a nossa posiçăo, somos obrigados a acrescentar que também ensinamos nos cursos da universidade, escrevemos artigos e livros, pesquisamos na biblioteca para preparar uma tese, somos envolvidos inevitavelmente pela burocracia em reuniōes e planejamento. E - por que náo? estudamos coleçóes de objetos arqueológicos escavados ou encontrados por outras pessoas. Estes vestígios materiais das culturas do passado foram recolhido por inúmeros colecionistas e mesmo por arqué́logos, ao longo do tempo, e se encontram em museus ou em coleçôes privadas. Seu estudo é uma fonte de informaçōes não negligenciáveis e de importância extraordinária para a reconstituição do passado. Este é exatamente o caso desta publicaçáo do arqueólogo Dr. Klaus Hilbert, professor da recentemente criada Área de Concentração em Arqueologia, do Pós-Graduaçăo em História da Pontifícia Universidade Católica do Rio Grande do Sul.

Estudos Ibero-Americanos. PUCRS, v. XVIII, n. 1, p. 105108, julho, 1992 
Como convenceríamos o público ou nossos colegas da necessidade de fazer uma "arqueologia de coleçōes"? Não será ela muito descritiva? Ou apenas uma versão moderna do colecionismo que caracterizou a arqueologia no passado? Ou um quebra cabeça incompleto, um jogo do qual temos poucas peças, na medida em que os vestígios arqueológicos não mais se encontram "in situ" e não possuem mais as relações com a estratigrafia ou a distribuiçăo espacial? Podemos nós estudar coleçōes de objetos encontrados muitas vezes por leigos e portanto sem muitas das informaçóes consideradas fundamentais pela ciência arqueológica?

Os arqueólogos tem como fazer "falar" os objetos destas coleçס̄es, oprotunizando pois novas interpretações sobre o passado remoto. É possível decodificar as informaçốes, comparar os dados obtidos com os de outras coleçôe provenientes de escavações recentes. Podemos sempre organizar de maneira coerente e interpretar estes dados. O livro de Klaus Hilbert nos mostra como isto é possível.

Seu trabalho foi realizado a partir de coleçôes de vestígios arqueológicos reunidos em museus e em coleçóes particulares na República Oriental do Uruguai. As pesquisas foram desenvolvidas em Montevidéu, Canelones, Nueva Palmira, Mercedes, Tacuarembo, Salto e Artigas. Através destes dados, foi possível uma reconstituiçăo das culturas mais importantes produzidas pelos grupos indígenas que se instalaram no atual Uruguai, no longínquo passado pré-histórico.

Pode esta cultura material ser uma boa fonte histórica para a reconstituiçăo do passado? Qual a importância da cultura material? Porque trabalhar com coleções arqueológicas? Sabemos que alguns historiadores e todos os arqueólogos tem utilizado a cultura material como fonte para as suas descrições, análises e sínteses sobre o passado. Entretanto, mesmo que esta temática normalmente nâo seja definida de maneira explícita, os pesquisadores conseguem circunscrever o campo da pesquisa. Para Jean-Marie Pesez, "a cultura material tem uma evidente relação com os condicionamentos materiais que pesam sobre a vida do homem e às quais ele opôe uma resposta que é exatamente a cultura. Mas a cultura material não é todo o conteúdo que concerne esta resposta. (...) a cultura material se situa mais para o lado das infra-estruturas, mas náo as recobre: ela apenas se exprime no concreto, nos e pelos objetos" (3). Para os arqueólogos, săo fundamentais os elementos que resultam de suas decodificaçóes dos vestígios materiais da cultura. Dentre eles, podemos destacar: as seqüências de gestos técnicos, as atividades padronizadas, o uso quotidiano de utensílios e de recipientes, as relações entre forma e função dos objetos. Em suma, tudo aquilo que dá vida às grandes maiorias silenciosas da história. As pesquisas relativas às condiçóes materiais tem a grande vantagem de reintroduzir os processos vividos do quotidiano. Isto significa: a valorização dos objetos, dos utensílios e do 
próprio homem como meios de trabalho; a exploração das riquezas materiais e das fontes de matéria-prima como objetivos de trabalho e da produçáo; as técnicas e as experiências acumuladas pela sociedade humana no processo de produção, etc. Poderíamos completar dizendo que esta reduçáo ao concreto e à realidade do passado, reequilibra os pratos da balança do julgamento dos historiadores, às vezes muito inclinado para o lado da metafísica e das construçôes intelectuais muito imaginativas. (4)

O livro de Klaus Hilbert nos exemplifica como se organizam os dados materiais da cultura estudados para compor uma síntese das tradiçōes líticas e cerâmicas préhistóricas uruguaias. Desta maneira se estrutura um quadro de referências, que nos evidencia quais os dados que possuímos hoje sobre os primeiros caçadores-coletores e os denominados caçadores especializados, bem como sobre os grupos que já dominavam as técnicas da elaboração da cerâmica. Ele é ilustrado com 135 figuras, entre fotos, desenhos e mapas, que nos dão uma amostra perfeita das inúmeras culturas pré-históricas que se encontram no Uruguai. Os belíssimos desenhos dos artefatos líticos pré-históricos nos evidenciam uma amostragem significativa dos principais tipos caracterizadores da cultura material de cada um destes grupos pré-históricos uruguaios que ali viveram ao longo de aproximadamente 10.000 anos. Seu livro apresenta ainda um resumo das principais atividades de investigação arqueológica que se desenvolveram no Uruguai neste século. Nos mostra igualmente uma síntese dos conhecimentos etnohistóricos sobre os grupos indígenas que foram encontrados e descritos pelos espanhóis e portugueses quando penetram no espaço do Rio da Prata. A bibliografia apresentada nas páginas finbais do texto é exaustiva.

Uma série de questóes, entretanto, nos intrigam e ao mesmo tempo nos sugerem algumas respostas. Quais os limites e as possibilidades, do ponto de vista metodológico da arqueologia do uso de coleçōes de vestígios arqueológicos, para a reconstituiçăo histórica do passado? Sabemos que sáo limites importantes o fato de ter sido feita a coleta destes utensílios arqueológicos por leigos sem formação arqueológica, bem como a constatação de que não é toda a cultura que sobreviveu nestes vestígios. Desde a etapa em que sociedades pré-históricas viviam a sua realidade histórica, até o momento em que o nosso estudo atual se debruça sobre os vestígios encontrados nas coleçōes, a informação possível "sofreu tais açōes de destruiçăo, de mutilação, de deformação que é legítio que se coloque a questâo da significação e da pertinência deste 'resíduo' de informação de que nós dispomos. Temos direito, 'a la limite', de nos perguntar se a documentaçáo existente é susceptível de suscitar uma imagem representativa da realidade primitiva" (5). Quanto às possibilidades, elas são importantes, pois não podemos negligenciar o resultado final do trabalho. Ele é uma síntese 
cronologica das principais culturas pré-históricas que se evidenciaram ao longo do tempo, no Holoceno do que atualmente é a República do Uruguai.

Ao afirmar que seu trabalho deveria se constituir em "um incentivo à discussáo e futuras pesquisas" (6), o autor se refere por um lado às próprias críticas que surgiráo a favor ou contra a síntese proposta, bem como ao desafio que representa para os arqueólogos do país vizinho à ida a campo para comprovar ou contestar as afirmaçóes propostas pelo autor.

Finalmente, somos obrigados a concluir afirmando que este trabalho veio alterar a visáo que antes se tinha da Arqueologia do Uruguai. A sua grande contribuiçáo conclusiva para o período pré-histórico foi exatamente o de realizar nova e mais completa síntese, reunindo os dados existentes nass coleçóes de vestígios arqueológicos, algumas delas existentes já desde o século passado.

Klaus Hilbert atinge em seu livro o objetivo que se havia proposto, qual seja o de "ofrecer una visión de conjunto de las tradiciones indígenas más importantes del Uruguay partiendo de las tradiciones temprenas del paleoindio, hasta llegar a los tiempos de la conquista" (7). Esperamos que outras iniciativas como estas possam ter como objetivo o estudo das coleçóes arqueológicas do sul do Brasil. Estaríamos assim não apenas evitando que estas informaçōes permaneçam desconhecidas, mas favorecendo igualmente as interpretaçóes comparativas.

- Curso de Pós-Graduação em História

Dept $^{\bullet}$ de História - IFCH

PUCRS

Porto Alegre - RS

\section{NOTAS}

(1) HILBERT, Klaus. Aspectos de la arqueologia en el Uruguay. Mainz am Rheim, Verlag Philipp von Zabern, 1991. A presente apresentação do livro foi feita, em 24/06/1992, no encontro "Publicaçōes recentes do Pós-Graduação em História (Docente e Discente)", destinado à divulgação da produção intelectual do Curso de Pós-Graduação em História da PUCRS.

(2) SCHNAPP, Alain (dir.). L'archeologhie aujourd'hui. Paris, Hachette, 1980. p. 87.

(3) PESEZ, Jean Marie. "Histoire de la culture matérielle". In: LE GOFF, J. (dir.). La nouvelle histoire. Bruxelas, Complexe, 1988. p. 194.

(4) As afirmações acima foram publicadas em: KERN, Arno Alvarez. A cultura material, a História e a Arqueologia. Anais (Va Reunião da Junta Regional de História, Montevidéu, Uruguai), 12-14 out/1992.

(5) DELPORTE, Henri. Archéologie et realité. Paris, Picard, 1984. p. 127.

(6) HILBERT, Klaus. Opus cit., p. 46.

(7) HILBERT, Klaus. Locus cit. 